\title{
Research on the Signal Effect of Performance Compensation Commitment on the Impairment of Goodwill in China
}

\author{
Qiandan Deng \\ School of Economics and Business Administration, Chongqing University, PR China \\ Shabei st. 83, Shapingba District, 400030, Chongqing, China \\ E-mail.dengqiandan@126.com \\ cross $^{r e f}$ http://dx.doi.org/10.5755/i01.ee.30.5.22892
}

This study using empirical research method and taking 1233 samples of A-share listed companies in China that completed major asset restructuring from 2007 to 2017, examines the signal effect of performance compensation commitment on goodwill impairment, and the impact of agency motivations on the signal effect based on the proportion of the performance compensation commitment that $M \& A$ targets achieve. I find evidence suggesting that the higher the proportion of the unfulfilled performance compensation commitment is, the higher the probability of goodwill impairment and the greater the amount of goodwill impairment. In addition, agency motivations affect the signal effect of performance compensation commitment on the impairment of goodwill. Specifically, for companies facing market return pressure and debt contracting pressure, the signal effect of the performance compensation commitment on the impairment of goodwill will be weakened. Furthermore, companies with performance loss have the incentive to use goodwill impairment to carry out a "big bath" and the loss motivation will lead to the overexpression of the signal effect of performance compensation commitment on goodwill impairment. The findings of this paper provide a new perspective for external users of financial statements to observe goodwill impairment and help them better understand managers' opportunistic motivations to accrue goodwill impairment.

Keywords: Performance Compensation Commitment; Goodwill Impairment; Agency Motivations; Fair-Value Accounting; Earnings Management.

\section{Introduction}

Recently, the Accounting Department of the China Securities Regulatory Commission issued the "Accounting Supervision Risk Warning No. 8 - Goodwill Impairment" document. The risk of goodwill impairment in the A-share market in China has once again become a hot topic. According to statistics from WIND which is a professional database in China, as of the end of the third quarter of 2018, the amount of goodwill for A-share listed companies reached 1.45 trillion yuan, representing a year-on-year increase of $15.18 \%$, a $4.05 \%$ increase from the previous month, and a breakthrough of 1.4 trillion yuan for the first time. ${ }^{1}$ The scale of goodwill has expanded so rapidly that it cannot be separated from policy support. In the early stage, to encourage listed companies to become larger and stronger through mergers and acquisitions (M\&As), regulators reduced the interval time for reorganization from three years to six months for companies facing IPO rejection and supported listed companies in targeting issued convertible bonds as a payment instrument in the reorganization. Although M\&As have injected new vitality into companies and introduced new growth points, M\&As are a doubleedged sword for listed companies. On the one hand, good management of the target assets can contribute to the growth of the company's performance; on the other hand, if the performance of the target assets is poor, the goodwill

\footnotetext{
${ }^{1}$ The statistics are come from the WIND database, which is a professional database in China. Many Chinese scholars engaged in scientific research use data downloaded from WIND. The authority of the database is recognized by Chinese scholars.
}

impairment loss will reduce the company's net profit. Generally speaking, the greater the proportion of goodwill is within the company's net assets, the greater the impact on the financial data of listed companies' profits when the goodwill is impaired (Zang, 2008). Moreover, after goodwill is impaired, the company directly changes from profiting to incurring losses. For example, according to the annual report disclosed by Xin Li Finance, the operating income realized by Xin Li Finance (600318) in 2017 was approximately 633 million yuan, representing a decrease of $21.95 \%$ compared with the same period of the previous year. During the reporting period, the Xin Li Finance net profit loss attributable to the shareholders of listed companies was approximately 309 million yuan, representing a decrease of $289.8 \%$ compared with 2016. Because of the decreased performance, Xin Li Finance indicated that it had incurred a provision of goodwill impairment amounting to 352 million yuan (Beijing Business Daily/ 2018/ April/ 13/ Version006). ${ }^{2}$ In addition, Bus Online (002188), Key Bridge Communication (002316), Watson Bio (300142) changed from profiting to incurring losses due to the impairment of goodwill. Currently, the issue of "Trillion" goodwill impairment has a looming threat to listed companies and has attracted the attention of all relevant parties. Therefore, it is of great practical significance to study the issue of goodwill impairment.

\footnotetext{
${ }^{2}$ The statistics are published by the 2016 and 2017 financial annual reports of listed company of Xin Li Finance (600318).
} 
After the convergence with International Accounting Standards, the implementation of China's new "Enterprise Accounting Standards" in 2007 eliminated goodwill amortization and introduced the evaluation of the impairment test at least annually. Standard setters believe that the goodwill impairment test can provide more relevant information and improve the quality of financial statement information relative to amortization. However, the unverifiable fair-value estimation causes managers to have greater discretion in the goodwill impairment test. Agency theory predicts that managers will, on average, use unverifiable discretion in SFAS 142, consistent with private incentives (Ramanna \& Watts, 2012). The subsequent changes in the accounting treatment of goodwill have a significant impact on the users of financial statements. Due to the unverifiability of the fair-value estimation, the goodwill impairment test contains many uncertainties. Moreover, external users are in at an information disadvantage relative to managers, and it is difficult for them to judge problems such as whether managers recognize the amount of goodwill impairment and whether the timing of goodwill impairment is correct. Specifically, owing to the complexity of impairment tests, for regulators, the existence of opportunism increases regulatory risk. For auditors, the difficulty and risk involved in auditing have increased. For investors, information asymmetry has increased, making investment decisions difficult. For creditors, the risk of debt contracting has increased. However, it is difficult for external users to judge whether a manager's choice of goodwill impairment is correct because it is difficult to find a signal of whether goodwill is impaired. According to the definition of goodwill, the performance of the target can help identify the risk of goodwill impairment.

China's "Administrative Measures on Major Asset Restructuring of Listed Companies", which was implemented on May 18, 2008, clearly stipulates the following: An asset appraisal institution's evaluation of purchased assets must be based on estimations of present value, such as the present value of income method or the hypothetical development method, and used as a reference for pricing the target. A listed company shall separately disclose the difference between the actual profit of relevant assets and the predicted profit in the assessment reports within 3 years after the completion of the major asset restructuring. The auditor shall issue a special review opinion about the assessment reports, and the counterparty shall sign a clear and feasible performance compensation commitment agreement with the listed company expressing that the actual profit of the relevant assets is less than the predicted profit. However, after a merger, the control rights of the M\&A target are shifted to the listed company, and the actual profit of the M\&A target is separately disclosed. This means that these assets must remain in their original state and be accounted for separately, which is not conducive to business integration after the merger. Therefore, the "Administrative Measures on Major Asset Restructuring of Listed Companies" implemented on November 23, 2014, canceled the mandatory provisions of performance compensation commitment agreements for listed companies that purchase assets from unrelated third parties. However, due to the high degree of market-based games in this M\&A transaction, the cancelation of mandatory compensation regulations has little effect on the signing of performance compensation commitment agreements. To protect their own interests, listed companies still generally require the counterparty to sign a performance compensation commitment agreement. In addition, in cases where the counterparty is no longer involved in the operation, some controlling shareholders of listed companies make performance compensation commitments regarding the future profitability of the M\&A target. The "Accounting Supervision Risk Warning No. 8 - Goodwill Impairment" document suggests seven specific signs of goodwill impairment that should be tested in a timely manner, and unrealized performance compensation commitment is the first sign. Therefore, external users can judge goodwill impairment through the realization of performance compensation commitment.

Taking A-share listed companies in China that completed major asset restructuring from 2007 to 2017 as a sample, this paper examines the signal effect of performance compensation commitment on the impairment of goodwill and the impact of agency motivations on signal effects based on the proportion of the performance compensation commitment achieved by the M\&A target. I find evidence suggesting that the higher the proportion of the unfulfilled performance compensation commitment is, the higher the probability of goodwill impairment and the greater the amount of goodwill impairment. In addition, agency motivations affect the signal effect of performance compensation commitment on the impairment of goodwill. Specifically, for companies facing market return pressure and debt contracting pressure, the signal effect of the performance compensation commitment on the impairment of goodwill will be weakened. Furthermore, companies with performance loss have the incentive to use goodwill impairment to carry out a "big bath" and the loss motivation will lead to the overexpression of the signal effect of performance compensation commitment on goodwill impairment. The findings of this paper provide a new perspective for external users of financial statements to observe goodwill impairment and help them better understand managers' opportunistic motivations to accrue goodwill impairment.

The main contributions of this paper are as follows. First, there is few study on the issue of goodwill impairment from the perspective of performance compensation commitment. If the target's profitability declines, goodwill may be impaired. Therefore, the achievement of the performance compensation commitment of the M\&A target can be used as a sign of goodwill impairment to help external users of financial statements judge whether goodwill is impaired and whether the manager's decision regarding goodwill impairment is correct. Second, the literature on goodwill impairment in foreign countries is based on the company level; it does not distinguish the different asset groups that bring different goodwill and regarding the ratio of book-to-market value that is greater than one as a sign of goodwill impairment (Ramanna \& Watts, 2012). However, this paper considers the goodwill impairment of a single asset group using the achievement of the performance compensation commitment of the target of 
M\&A as a sign of goodwill impairment, which is more direct and suitable for studying goodwill impairment. Third, the findings enrich the signal theory literature.

\section{Literature Review}

\section{Literature on Goodwill Impairment}

Goodwill arises in the process of M\&A, and the accounting treatment of goodwill changes as the accounting treatment of M\&A changes. Prior to SFAS 142, accounting for acquired goodwill was governed by APB 17 (AICPA 1970) and SFAS 121 (FASB 1995). Under these standards, firms had the option to account for acquisitions using the pooling-of-interests method, thereby avoiding goodwill recognition altogether. Goodwill, when recognized, was subject to periodic amortization. However, SFAS 142, which was promulgated in 2001, abolished goodwill amortization and instead required an impairment-only approach to goodwill. Ramanna (2008) noted that the goodwill impairment test is a compromise choice for prospective developers in the face of political pressure. Due to the unverifiability of fair-value estimation, the new standard has increased the discretionary power of managers. Based on the unverifiable discretion of the goodwill impairment test, many scholars have conducted in-depth studies on the motivations of managers to recognize goodwill impairment (Beatty \& Weber, 2006; LapointeAntunes et al., 2008; AbuGhazaleh et al., 2011; Hamberg et al., 2011; Onesti \& Romano, 2012; Ramana \& Watts, 2012; Giner \& Pardo, 2015; Iatridi \& Senftlechner, 2014; Filip et al., 2015; Li \& Sloan, 2017; Glaum et al., 2018), information transmitted by goodwill impairment (Holthausen \& Watts ; Bens et al., 2011; Bostwick et al., 2015; Knauer, 2016; Qu et al., 2017), and the consequences of recognizing goodwill impairment (Darrough et al., 2014; Rehman \& Shahzad, 2014; Qu et al., 2017).

Beatty \& Weber (2006) specifically examined the motivations of managers to recognize goodwill impairment. They showed that stock market expectation, debt contracting default risk, manager compensation, executive turnover and listed company delisting crises will affect managers' choice of goodwill impairment. The goodwill impairment test is based on a comparison of the present value of future cash flows and book value, which standard setters believe can convey more private information about a company's cash flow. Ramanna \& Watts (2012) examined the reasons why company may have signs of impairment but may not be impaired. The article did not find the motivations to transmit the company's private information, but it did find agency incentives to influence the manager's choice of goodwill impairment, as shown in CEO compensation, CEO reputation and debt contracting default risk. Chen et al. (2015) demonstrated that although analysts incorporate information on goodwill impairment into forecasts, the accuracy of the forecasts is still reduced, and the dispersion of the forecast still increases, which indicates that the manager uses discretion of goodwill impairment. Li \& Sloan (2017) found that due to the influence of manager discretion, the timeliness of the goodwill impairment cannot be guaranteed, resulting in a large amount of goodwill on the balance sheet. Once impairment occurs, it is likely to decrease performance. They believe that the combination of system amortization and periodic impairment tests may better reflect the potential economic value of goodwill. Kothari et al. (2010) also noted that due to the inherent subjectivity in the process of the goodwill impairment test, managers are not more responsible for M\&A, but the amortization of goodwill makes managers have scruples. Filip et al. (2015) proved that managers increased the current cash flow of the company through real earnings management to achieve the purpose of postponing or not recognizing goodwill impairment.

The content of goodwill impairment is also a focus among scholars. Under normal circumstances, goodwill impairment is bad news for company stakeholders. The impairment of goodwill means a decline in the future cash flow of the asset group. Many scholars have studied investors' and analysts' reaction to announcements of goodwill impairment. Qu et al. (2017) found that the impairment of goodwill is negatively correlated with stock price and stock returns, indicating that investors negatively evaluate companies with goodwill impairment. Knauer (2016) suggested that the value of the information related to goodwill impairment is dependent on the explanation regarding the reasons for this impairment. When a company provides internal reasons, investors' reaction is more negative because internal reasons are unlikely to be confirmed by investors, and it indicates that managers are more likely to opportunistically disclose the goodwill impairment. The article also found that the legal environment and investor protection can also limit manager discretion, thereby improving the reliability of public information. However, due to the complexity and subjectivity of the goodwill impairment test, some scholars have questioned whether the impairment of goodwill can provide more relevant information to users of financial statements. Li et al. (2011) demonstrated that after the adoption of SFAS 142 standard, the negative reaction of investors and analysts to goodwill impairment decreased, indicating that external users were aware of the unverifiable discretion of the goodwill impairment test.

Less research has examined the consequences of goodwill impairment for companies. Darrough et al. (2014) found that when a company recognizes the impairment of goodwill, the CEO's cash compensation and option salary will decrease. In addition, Carcello et al. (2019) showed that the probability of auditor dismissal is associated with goodwill impairment, Ayres et al.(2019) indicated that the non-audit fees a client pays are inversely related to the likelihood of impairment in settings where goodwill is likely to be impaired.. Some studies examine goodwill impairment from other aspects. For example, Gu \& Lev (2011) revealed that the fundamental reason for goodwill impairment is that the buyer's stock price is overpriced. Consistent with their findings, Li et al. (2011) also demonstrated that the reason for goodwill impairment was the overpayment for the target by the acquirer. Additionally, some other studies found the positive effect of the SFAS 142. Cheng et al. (2018) proved that the annual assessment of the fair value of the reporting unit by the manager will prompt the manager to collect new information about the reporting unit so that the company's future performance can be better predicted. Other researchers have demonstrated that the adoption of the 
SFAS 142 standard enhances the ability of goodwill to predict future operating cash flow, and manager discretion has no effect on the ability of goodwill to predict future cash flow (Jarva, 2009; Lee, 2011). Sapkauskiene et al. (2016), from the perspective of macroeconomics, found that economic crisis will affect the disclosure of corporate goodwill impairment. To obtain higher economic benefits when the economic environment recovers, enterprises are more inclined toward higher impairment during economic crisis to reserve profit space in the future.

\section{Literature on Performance Compensation Commitment}

In essence, performance compensation commitment is a kind of gambling agreement, which refers to a contract that two M\&A parties sign for future uncertainty when they reach a merger agreement. In the M\&A transaction, the conditions agreed upon are mainly based on the future performance of the target. If these performance conditions are not met, the transferor will give the purchaser a certain amount of cash or share compensation; this is a performance compensation commitment (Lv \& Han, 2014). Currently, the literature on performance compensation commitment mainly focuses on the impact of performance compensation commitment on the synergy effect of M\&As (Lv \& Han, 2014), the financial attributes of performance compensation commitment behavior (Zhao, 2012; Wang et al., 2016), the accounting treatment of performance compensation commitment and the evaluation of policy effects of performance compensation commitment (Xie, 2016).

LV \& Han (2014) studied the effect of performance compensation commitment on the M\&A synergy in M\&A transactions and examined how this effect influences the distribution of gains between the two parties. They showed that the introduction of performance compensation commitment remarkably increases the M\&A synergy effect mainly because of the signal function of such commitment. The financial attribute of performance compensation commitment behavior is manifested in the transaction between the listed company and the acquired party. Due to the uncertainty of future returns, the performance compensation commitment made by the seller is regarded as a European put option sold to the listed company. The premium paid by the listed company is the valuation premium part of the performance compensation commitment, which is a financial derivative (Zhao, 2012; Wang et al., 2016). Scholars have different views of the accounting treatment of performance compensation commitments. Zhao (2012) considered that when assets are traded, the performance compensation commitment should be recognized as a longterm equity investment or derivative option, and when performance compensation is received, actual income should be recognized as investment income. The China Securities Regulatory Commission Accounting Department (2013) expressed that the performance compensation commitment should be measured at fair value and attributed to financial assets or salable financial assets. The evaluation of the effectiveness of the performance compensation commitment policy has also received increasing attention from all parties. Wang et al. (2016) compared and analyzed the performance achievement rate in each performance achievement period of M\&A and noted a phenomenon of "high" performance compensation commitment in the process of M\&A for listed companies in China. Xie (2016) demonstrated that China's performance compensation commitment system has caused many problems, distorted the formation mechanism of market prices and damaged the interests of small and medium investors.

Based on the literature review, it can be seen from the findings of the existing literature that there are many problems of goodwill impairment test. Hayn \& Hughes (2006) found that the ability to predict goodwill impairment based on information provided in the financial statements is limited. Given the importance of goodwill impairment, this paper focuses on the signal effect of performance compensation commitment on goodwill impairment, helping external users of financial statements to identify the risk of goodwill impairment.

\section{Theoretical Analysis and Research Hypotheses}

Due to information asymmetry and the complexity of the goodwill impairment test, it is difficult for external users to judge whether managers' decision to recognize the goodwill impairment is correct. However, according to the "Accounting Supervision Risk Warning No. 8 - Goodwill Impairment" document issued by the China Securities Regulatory Commission on November 16, 2018, unrealized performance compensation commitment is a specific sign of goodwill impairment, and it is a signal that can be observed by external users. Therefore, external users can use the achievement of performance compensation commitments to assess the risk of goodwill impairment. If the performance of the target asset is poor, then the profitability of the target asset seriously declines, and the probability of impairment of goodwill is high. Therefore, based on the above analysis, this paper proposes the first research hypothesis:

H1A: Companies with higher unrealized proportion of performance compensation commitment made by the promised party of the M\&A target, are more inclined to disclose goodwill impairment.

H1B: Companies with higher unrealized proportion of performance compensation commitment made by the promised party of the M\&A target, are more inclined to disclose a larger amount of goodwill impairment.

Accounting treatment of goodwill has changed from amortization to the impairment test, and fair-value estimation is used extensively in the impairment test. Standard setters believe that fair-value estimation can better reflect the potential economic value of goodwill, providing more relevant financial information to report users and improving the quality of financial statements. However, due to the unverifiability of fair value, managers are given considerable discretion. According to agency theory (Jensen \& Meckling, 1976), opportunistic behavior arises when managers recognize goodwill impairment. Then, agency motivations affect the signal effect of the performance compensation commitment on the impairment of goodwill. Specifically, if impairment causes profits to fluctuate greatly, affecting the company's stock price or the risk of the company's debt contracting, then the manager is likely to recognize less impairment or even no impairment. In addition, if the company has incurred losses in the current 
year, managers will tend to make more goodwill impairment to pave the way for future performance, which is called the "big bath" motivation in the literature. Therefore, based on the above analysis, this paper proposes the second and third research hypotheses:

H2A: Companies which affected by market pressure and debt contracting pressure will lead the signal effect of the performance compensation commitment on the impairment of goodwill be weakened, and are more inclined not to disclose goodwill impairment.

H2B: Companies which affected by market pressure and debt contracting pressure will lead the signal effect of the performance compensation commitment on the impairment of goodwill be weakened, and are more inclined to disclose a smaller amount of goodwill impairment.

H3A: Companies which affected by the decrease in company performance will lead the overexpression of the signal effect of performance compensation commitment on goodwill impairment, and are more inclined to disclose goodwill impairment.

H3B: Companies which affected by the decrease in company performance will lead the overexpression of the signal effect of performance compensation commitment on goodwill impairment, and are more inclined to disclose a larger amount of goodwill impairment.

\section{Research Design}

\section{Sample Selection and Data Source}

This paper takes A-share listed companies in China that completed major asset restructuring from 2007 to 2017 as a sample, excluding the backdoor listings and listed companies that were seller or merger targets. First, goodwill data and performance compensation commitment data are matched with companies that completed major asset restructuring, and the missing data are manually supplemented. The missing data are found in the announcements of the performance compensation commitment and in the annual reports published by the listed companies. Goodwill data generated by each M\&A business come from the CSMAR which is a professional database in China, and performance compensation commitment data and major asset restructuring data come from WIND. After eliminating the missing data samples, the final sample size of this paper is 1233. To eliminate the influence of extreme values, $1 \%$ winsorized processing is performed on all continuous variables. The mathematical statistical analysis was performed by Stata 15 applications for statistical data processing.

\section{Variable Definitions}

Variable Definitions

Table 1

\begin{tabular}{|c|c|c|}
\hline Variable type & Variable name & Variable symbol \\
\hline \multirow{2}{*}{$\begin{array}{l}\text { Dependent } \\
\text { variables }\end{array}$} & Impaired dummy variable & Imp_dum \\
\hline & $\begin{array}{l}\text { Impaired continuous } \\
\text { variable }\end{array}$ & $\operatorname{Imp}$ \\
\hline \multirow{4}{*}{$\begin{array}{l}\text { Independent } \\
\text { variables }\end{array}$} & $\begin{array}{l}\text { Proportion of performance } \\
\text { compensation commitment }\end{array}$ & Proppmi \\
\hline & Market pressure & Ret \\
\hline & Debt contracting pressure & Lev \\
\hline & Loss pressure & Loss_dum \\
\hline \multirow{7}{*}{$\begin{array}{c}\text { Control } \\
\text { variables }\end{array}$} & CEO Turnover & CEOTurnover \\
\hline & CEO Age & CEOAge \\
\hline & Nature of property & Gov \\
\hline & Company size & Size \\
\hline & Goodwill ratio & PropGw \\
\hline & Book-to-market value ratio & $B T M$ \\
\hline & Age of listed company & Age \\
\hline
\end{tabular}

\section{Model Selection}

Since these are two-fold hypotheses encompassing different accounting decisions, the following distinct regression models are applied with regard to the present research: the binary logistic regression model, which involves the modelling of a binary dependent variable, and the linear regression model, which involves the modelling of an interval variable. In addition, considering that many values of goodwill impairment are zero, thus, this paper use the tobit model to estimate the impaired continuous variable(Imp) at the same time. The estimation results of the three models are all reported later.

In accordance with Beatty \& Weber (2006) and Ramanna $\&$ Watts (2012), this paper uses models 1 and 2 to examine the signal effect of performance compensation commitment on goodwill impairment. The binary logistic regression model and linear regression model are shown below.

\begin{tabular}{l} 
Variable definitions \\
A dichotomous variable equal to one if there is any impairment in the current \\
year $\mathrm{t}$. \\
Equal to the amount of goodwill impairment divided by the total assets at \\
the end of year $\mathrm{t}$ \\
$\begin{array}{l}\text { Equal to (promised performance in year } \mathrm{t} \text { minus real performance in year } \mathrm{t} \text { ) } \\
\text { divided by promised performance in year } \mathrm{t}\end{array}$ \\
$\begin{array}{l}\text { Equal to the annual return in year t estimated by monthly stock returns after } \\
\text { adjustment by market returns }\end{array}$ \\
\hline Equal to the liabilities divided by total assets of year $\mathrm{t}$ \\
\hline $\begin{array}{l}\text { A dichotomous variable equal to } \\
\text { one if the roe of year } \mathrm{t} \text { is less than } 0\end{array}$ \\
\hline A dichotomous variable equal to one if the CEO changed in year $\mathrm{t}$ \\
\hline Equal to the age of CEO \\
\hline A dichotomous variable equal to one if the property rights are state-owned \\
\hline Equal to the ln of total assets of year $\mathrm{t}$ \\
\hline Equal to amount of goodwill divided by total assets of year $\mathrm{t}$ \\
\hline Equal to total assets divided by market value \\
\hline Equal to the time which is from listed year to 2017 \\
\hline
\end{tabular}

Imp_dum $=\alpha+\beta_{1}$ Proppmi $+\beta_{2}$ Ret $+\beta_{3}$ Lev $+\beta_{4}$ Loss_dum $+\beta_{5}$ Gov $+\beta_{6}$ CEOTurnover $+\beta_{7}$ CEOAge $+\beta_{8}$ Size $+\beta_{9}$ PropGw $+\beta_{10}$ BTM $+\beta_{11}$ Age + Year + Ind $+\varepsilon$

Imp $=\alpha+\beta_{1}$ Proppmi $+\beta_{2}$ Ret $+\beta_{3}$ Lev $+\beta_{4}$ Loss dum $+\beta_{5}$ Go $\mathrm{v}+\beta_{6}$ CEOTurnover $+\beta_{7}$ CEOAge $+\beta_{8}$ Size $+\beta_{9}$ PropGw $+\beta_{10} \mathrm{~B}$ $\mathrm{TM}+\beta_{11}$ Age + Year + Ind $+\varepsilon$

When $\mathrm{H} 2 \mathrm{~A}, \mathrm{H} 2 \mathrm{~B}, \mathrm{H} 3 \mathrm{~A}$ and $\mathrm{H} 3 \mathrm{~B}$ are tested, some intersections are added to model 1 and model 2 . Specifically, Pro $\times$ Ret, Pro $\times$ Lev and Pro $\times$ Loss are added to model 1 and model 2 to examine the impact of agency motivations on the signal effect of performance compensation commitment.

\section{Empirical Results}

Descriptive Analysis of Study Sample 
Table 2

A Descriptive Analysis of Study Sample

\begin{tabular}{|c|c|c|c|c|c|c|c|}
\hline \multicolumn{2}{|c|}{ PERFORMANCE DATA / VARIABLES } & $\mathbf{N}$ & Max & Min & Mean & Median & SD \\
\hline \multirow{2}{*}{$\begin{array}{c}\text { Dependent } \\
\text { variables }\end{array}$} & Imp_dum & 1233 & 1 & 0 & 0.07 & 0 & 0.26 \\
\hline & $\operatorname{Imp}$ & 1233 & 0.098 & 0 & 0.00 & 0 & 0.01 \\
\hline \multirow{4}{*}{$\begin{array}{c}\text { Independent } \\
\text { variables }\end{array}$} & Propmi & 1233 & 1.4 & -1.7 & -0.06 & -0.032 & 0.31 \\
\hline & Ret & 1233 & 3.2 & -.64 & 0.22 & -0.085 & 0.80 \\
\hline & Lev & 1233 & 0.92 & 0.066 & 0.37 & 0.34 & 0.18 \\
\hline & Loss_dum & 1233 & 1 & 0 & 0.04 & 0 & 0.20 \\
\hline \multirow{7}{*}{$\begin{array}{c}\text { Control } \\
\text { variables }\end{array}$} & Gov & 1233 & 1 & 0 & 0.10 & 0 & 0.29 \\
\hline & CEOTurnover & 1233 & 1 & 0 & 0.27 & 0 & 0.45 \\
\hline & CEOAge & 1233 & 73 & 35 & 51.80 & 52 & 7.24 \\
\hline & Size & 1233 & 7.2 & 2.2 & 3.73 & 3.7 & 0.77 \\
\hline & Propgw & 1233 & 0.54 & 0.000072 & 0.14 & 0.11 & 0.12 \\
\hline & BTM & 1233 & 5.7 & 0.095 & 0.51 & 0.42 & 0.41 \\
\hline & Age & 1233 & 26 & 1 & 8.11 & 6 & 6.15 \\
\hline
\end{tabular}

Descriptive statistics of the variables of the samples in the regression models are shown in table 2 . As seen from the results, the mean value of the impaired dummy variable is 0.07 , indicating that the proportion of goodwill impairment in the sample is low. The mean of the ratio of goodwill impairment to total assets (median) is $0.00(0)$, the minimum value is 0 , and the maximum value is 0.098 , indicating a large difference in the cost of goodwill paid by listed companies. The mean of the unrealized proportion of performance compensation commitments is -0.06 (median 0.032 ), the minimum value is -1.7 , and the maximum value is 1.4 , indicating that the implementation of performance compensation commitment in the sample is quite different.
The mean of market return (median) is $0.22(-0.085)$ with a standard deviation of 0.8 , which indicates that there is a large difference in the market return of the observed samples. The mean of companies with debt contracting pressure is 0.37 , the proportion of losing companies is $4 \%$, and the proportion of state-owned enterprises is $10 \%$. During the sample period, $27 \%$ of the sample companies' CEO changed. The mean age of CEO is 51.8 years old, and the mean listing time of listed companies is 8.11 years. The values of descriptive statistics are consistent with those found in the literature.

\section{Correlation Test}

The Results of Correlation Analysis

Table 3

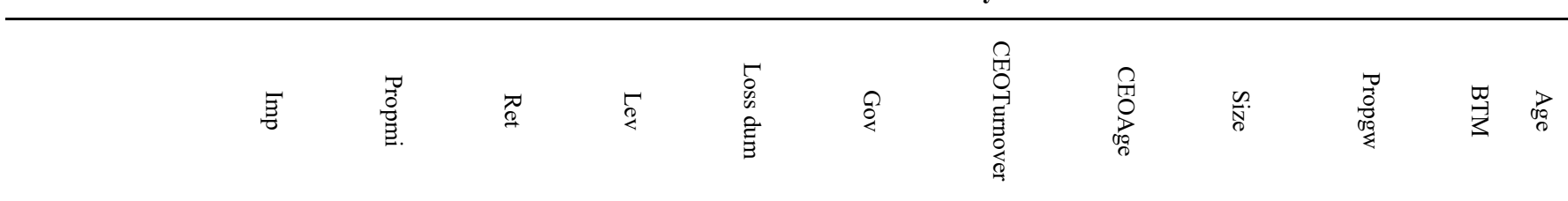

\begin{tabular}{|c|c|c|c|c|c|c|c|c|c|c|c|}
\hline Imp & 1 & & & & & & & & & & \\
\hline Propmi & $\begin{array}{c}0.37 * * * \\
(0.00)\end{array}$ & 1 & & & & & & & & & \\
\hline Ret & $\begin{array}{l}-0.05^{*} \\
(0.05)\end{array}$ & $\begin{array}{c}-0.12 * * * \\
(0.00)\end{array}$ & 1 & & & & & & & & \\
\hline Lev & $\begin{array}{c}0.09 * * * \\
(0.00)\end{array}$ & $\begin{array}{c}0.04 \\
(0.21)\end{array}$ & $\begin{array}{l}-0.04 \\
(0.15)\end{array}$ & 1 & & & & & & & \\
\hline Loss dum & $\begin{array}{c}0.47 * * * \\
(0.00)\end{array}$ & $\begin{array}{c}0.20 * * * \\
(0.00)\end{array}$ & $\begin{array}{l}-0.01 \\
(0.67)\end{array}$ & $\begin{array}{c}0.21 * * * \\
(0.00)\end{array}$ & 1 & & & & & & \\
\hline Gov & $\begin{array}{l}-0.02 \\
(0.58)\end{array}$ & $\begin{array}{l}0.06 * \\
(0.05)\end{array}$ & $\begin{array}{c}-0.10^{* * * *} \\
(0.00)\end{array}$ & $\begin{array}{c}0.10 * * * \\
(0.00)\end{array}$ & $\begin{array}{c}0.00 \\
(0.95)\end{array}$ & 1 & & & & & \\
\hline CEOTurnover & $\begin{array}{c}0.03 \\
(0.35)\end{array}$ & $\begin{array}{l}-0.01 \\
(0.79)\end{array}$ & $\begin{array}{c}0.01 \\
(0.81)\end{array}$ & $\begin{array}{c}0.07 * * \\
(0.02)\end{array}$ & $\begin{array}{c}0.08 * * * \\
(0.00)\end{array}$ & $\begin{array}{c}0.08 * * \\
(0.01)\end{array}$ & 1 & & & & \\
\hline Size & $\begin{array}{c}-0.06 * * \\
(0.02)\end{array}$ & $\begin{array}{l}-0.02 \\
(0.51)\end{array}$ & $\begin{array}{c}-0.20 * * * \\
(0.00)\end{array}$ & $\begin{array}{c}0.35 * * * \\
(0.00)\end{array}$ & $\begin{array}{l}-0.05 \\
(0.11)\end{array}$ & $\begin{array}{c}0.21 * * * \\
(0.00)\end{array}$ & $\begin{array}{c}0.13 * * * \\
(0.00)\end{array}$ & $\begin{array}{l}-0.02 \\
(0.52)\end{array}$ & 1 & & \\
\hline Propgw & $\begin{array}{c}0.21 * * * \\
(0.00)\end{array}$ & $\begin{array}{c}0.04 \\
(0.17)\end{array}$ & $\begin{array}{c}0.13 * * * \\
(0.00)\end{array}$ & $\begin{array}{c}-0.38 * * * \\
(0.00)\end{array}$ & $\begin{array}{c}0.08 * * * \\
(0.00)\end{array}$ & $\begin{array}{c}-0.13 * * * \\
(0.00)\end{array}$ & $\begin{array}{c}0.02 \\
(0.44)\end{array}$ & $\begin{array}{c}0.06 * * \\
(0.03)\end{array}$ & $\begin{array}{c}-0.32 * * * \\
(0.00)\end{array}$ & 1 & \\
\hline BTM & $\begin{array}{c}0.01 \\
(0.76)\end{array}$ & $\begin{array}{c}0.10 * * * \\
(0.00)\end{array}$ & $\begin{array}{c}-0.34 * * * \\
(0.00)\end{array}$ & $\begin{array}{c}0.48 * * * \\
(0.00)\end{array}$ & $\begin{array}{c}0.04 \\
(0.21)\end{array}$ & $\begin{array}{c}0.22 * * * \\
(0.00)\end{array}$ & $\begin{array}{c}0.07 * * \\
(0.02)\end{array}$ & $\begin{array}{c}-0.02 \\
(0.41)\end{array}$ & $\begin{array}{c}0.54 * * * \\
(0.00)\end{array}$ & $\begin{array}{c}-0.28 * * * \\
(0.00)\end{array}$ & 1 \\
\hline Age & $\begin{array}{c}0.01 \\
(0.66)\end{array}$ & $\begin{array}{c}0.04 \\
(0.15) \\
\end{array}$ & $\begin{array}{c}-0.18 * * * \\
(0.00)\end{array}$ & $\begin{array}{c}0.28 * * * \\
(0.00)\end{array}$ & $\begin{array}{c}0.15^{* * * *} \\
(0.00)\end{array}$ & $\begin{array}{c}0.41 * * * \\
(0.00)\end{array}$ & $\begin{array}{c}0.23 * * * \\
(0.00)\end{array}$ & $\begin{array}{c}0.03 \\
(0.26)\end{array}$ & $\begin{array}{c}0.37 * * * \\
(0.00)\end{array}$ & $\begin{array}{c}-0.12 * * * \\
(0.00)\end{array}$ & $\begin{array}{c}0.31 * * * \\
(0.00)\end{array}$ \\
\hline
\end{tabular}

Note:p-values in parentheses, *,**,**indicate statistical significance at the $10 \%, 5 \%$, and $1 \%$ levels, respectively 
Table 3 describes the correlation coefficient between variables. As shown, the correlation coefficient between Propmi and Imp is 0.37 , significant at the $1 \%$ level, which indicates that the unrealized proportion of performance compensation commitment is positively correlated with the impaired continuous variable. That is, the worse the performance of the M\&A target is, the greater the amount of goodwill impairment. The correlation coefficient between Ret and Imp is -0.05 , significant at the $10 \%$ level. This indicates that the market return variable is negatively correlated with the impaired continuous variable, and when the company is facing stock market pressure, managers are inclined to recognize less goodwill impairment. This finding coincides with the studies (Ramanna \& Watts, 2012; Li \& Sloan, 2017). A host of studies document a tendency to avoid accounting choices that negatively affect balances included in debt covenants calculations (Beatty et al., 2002; Dichev \& Skinner, 2002; Beatty \& Weber, 2006). Because of higher leverage will increase the probability of violating debt covenants. Hence, highly indebted firms are expected to avoid goodwill impairments. But, the correlation coefficient between Lev and Imp is 0.09 , positive significant at the $1 \%$ level. This finding is in contrary to the results of the studies carried out by Beatty \& Weber (2006), Zang (2008), AbuGhazalech et al. (2011), as well as Ramanna \& Watts (2012), but coincides with studies carried out by Jahmani (2010) and Sapkauskiene et al. (2016) .The correlation coefficient between Loss_dum and Imp is 0.47 , significant at the $1 \%$ level. This indicates that the loss of performance variable is positively correlated with the impaired continuous variable, and if the company has already lost, the manager will tend to recognize more goodwill impairment to carry out a "big bath". This finding coincides with studies carried out by (AbuGhazalech et al., 2011; Giner \& Pardo, 2015). In addition, the higher the proportion of goodwill to total assets is, the greater the amount of goodwill impairment. This finding coincides with the studies (Zang, 2008; Ramanna \& Watts, 2012). The greater the book-to-market ratio is, the greater the amount of goodwill impairment.

The analysis of the variable correlations shows that their coefficients are not of great importance to cause concern for multicollinearity problem.

\section{Comparative Descriptive Statistics}

Comparative Descriptive Statistics between Unimpaired Group and Impaired Group

\begin{tabular}{c|cc|cc|c}
\hline \multirow{2}{*}{ Variables } & \multicolumn{2}{|c|}{ Unimpaired group } & \multicolumn{2}{|c|}{ Impaired group } & \multirow{2}{*}{ Meandiff } \\
\cline { 2 - 5 } Propmi & $\mathbf{N}$ & -0.100 & $\mathbf{N}$ & 0.435 & $-0.535^{* * *}$ \\
Ret & 1141 & 0.249 & 92 & -0.117 & $0.366^{* * *}$ \\
Lev & 1141 & 0.364 & 92 & 0.420 & $-0.056^{* * *}$ \\
Loss_dum & 1141 & 0.0260 & 92 & 0.228 & $-0.202^{* * *}$ \\
Gov & 1141 & 0.0960 & 92 & 0.0870 & 0.00900 \\
CEOTurnover & 1141 & 0.273 & 92 & 0.283 & -0.00900 \\
CEOAge & 1141 & 51.77 & 92 & 52.21 & -0.441 \\
Size & 1141 & 3.724 & 92 & 3.775 & -0.0510 \\
Propgw & 1141 & 0.142 & 92 & 0.172 & $-0.029 * *$ \\
BTM & 1141 & 0.506 & 92 & 0.604 & $-0.099^{* *}$ \\
Age & 1141 & 8.117 & 92 & 8.022 & 0.0950 \\
\hline
\end{tabular}

Note:*, *****indicate statistical significance at the $10 \%, 5 \%$, and $1 \%$ levels, respectively

Table 4 shows the mean difference test of each variable between the impaired group and the unimpaired group. As shown from the results, the mean difference in Propmi between the two groups is 0.535 , significant at the $1 \%$ level. This indicates that the unrealized proportion of the performance compensation commitment of the impaired group is significantly higher than that of the unimpaired group. The mean difference in Ret between the two groups is 0.366 , significant at the $1 \%$ level. This indicates that the market return rate of the unimpaired group is significantly higher than that of the impaired group and that when the company is facing stock market pressure, managers are inclined to recognize less goodwill impairment. The mean difference in Lev between the two groups is 0.056 , significant at the $1 \%$ level. This finding coincides with the studies by the scientists Jahmani (2010) and Sapkauskiene et al. (2016), which found that the more indebted companies are likely to disclose the goodwill impairment, and are likely to disclose larger amount of goodwill impairment. The mean difference in Loss_dum between the two groups is 0.202 , significant at the $1 \%$ level. This indicates that the performance decrease in the impaired group is significantly greater than that in the unimpaired group, and if the company has already lost, a manager will tend to recognize more goodwill impairment. The ratio of goodwill to total assets and the book value to market value of the impaired group are significantly higher than those of the unimpaired group. This indicates that the higher the amount of goodwill at the beginning of the period and the higher the book value ratio are, the higher the probability of goodwill impairment in the future.

\section{Multivariate Results}


Table 5

Regression Analysis of the Signal Effect of Performance Compensation Commitment on Goodwill Impairment

\begin{tabular}{lccc}
\hline & $\mathbf{( 1 )}$ & $\mathbf{( 2 )}$ & $\mathbf{( 3 )}$ \\
& $\mathbf{I m p} \mathbf{d}$ dum & $\mathbf{I m p}$ & $\mathbf{I m p}$ \\
\hline Propmi & $12.055^{* * *}$ & $0.014^{* * *}$ & $0.101^{* * *}$ \\
& $(5.76)$ & $(6.47)$ & $(10.75)$ \\
Ret & -0.353 & $-0.001^{* *}$ & -0.007 \\
& $(-0.61)$ & $(-1.99)$ & $(-1.08)$ \\
Lev & 1.075 & $0.008^{* *}$ & 0.000 \\
& $(0.67)$ & $(2.29)$ & $(0.01)$ \\
Loss_dum & $2.246^{* * *}$ & $0.028^{* * *}$ & $0.042^{* * *}$ \\
& $(3.62)$ & $(4.65)$ & $(4.92)$ \\
Gov & -0.512 & 0.002 & -0.005 \\
& $(-0.54)$ & $(1.11)$ & $(-0.43)$ \\
CEOTurnover & 0.498 & -0.001 & 0.003 \\
& $(1.28)$ & $(-0.95)$ & $(0.47)$ \\
CEOAge & $0.058^{* *}$ & -0.000 & $0.001^{* *}$ \\
& $(2.16)$ & $(-0.23)$ & $(2.03)$ \\
Size & 0.198 & 0.000 & 0.005 \\
& $(0.64)$ & $(0.49)$ & $(1.01)$ \\
Propgw & $4.226^{* *}$ & $0.023^{* * *}$ & $0.103^{* * *}$ \\
& $(2.43)$ & $(4.30)$ & $(5.05)$ \\
BTM & 0.334 & $-0.002^{* *}$ & 0.009 \\
& $(0.42)$ & $(-2.03)$ & $(0.99)$ \\
Age & $-0.117^{* * *}$ & -0.000 & $-0.001^{* *}$ \\
& $(-3.03)$ & $(-1.05)$ & $(-2.19)$ \\
cons & -13.426 & -0.002 & $-0.151^{* * *}$ \\
& $(-0.59)$ & $(-0.52)$ & $(-4.07)$ \\
\hline Year & Yes & Yes & Yes \\
Ind & Yes & Yes & Yes \\
\hline N & 990 & 990 & 990 \\
Adj.R-Square/ & 0.621 & 0.415 & 0.315 \\
Pseudo.R-Square & & & \\
\hline & & &
\end{tabular}

Note: $* * *, * *$ indicate statistical significance at the $10 \%, 5 \%$, and $1 \%$ levels, respectively. $t$-values in parentheses.

Table 5 shows the results of the regression analysis of the signal effect of performance compensation commitment on goodwill impairment. The first column is the regression result of the binary logit model, the second column is the linear regression result of the ols model, and the third column is the censored regression result of the tobit model. Under the control of factors that may affect the impairment of goodwill, the coefficients of Propmi are 11.59, 0.014 and 0.101, all significant at the $1 \%$ level. This indicates that the higher the unrealized proportion of performance compensation commitment is, the higher the probability of goodwill impairment and the greater the amount of goodwill impairment. Moreover, the achievement of the performance compensation commitment can be used as a signal of goodwill impairment, which is consistent with the prediction of $\mathrm{H} 1 \mathrm{~A}$ and H1B. In addition, as shown in table 5, the coefficient of Ret is negative significant., coinciding with the study (Ramanna \& Watts, 2012). The coefficient of Lev is positive significant, which is in contrary to the results of the studies carried out by Zang (2008), AbuGhazalech et al. (2011), as well as Ramanna \& Watts (2012), but coincides with studies carried out by Jahmani (2010) and Sapkauskiene et al. (2016). Meanwhile, the coefficients of Loss_dum are all positive significant at the $1 \%$ level, which coincides with studies carried out by (AbuGhazalech et al., 2011; Giner \& Pardo, 2015). What's more, the coefficient of the variable Gov is insignificant, indicating that the nature of property rights has no influence on recognition of goodwill impairment. Another, the coefficient of the variable CEOTurnover is insignificant, which is in contrary to the conclusions made by Beatty and Weber (2006), Lapointe-Antubes et al. (2008), Abughazalech et al. (2011), Ramana \& Watts (2012), Hamberg et al. (2011), and Sapkauskiene et al. (2016). The coefficients of CEOAge are 0.058 and 0.001 , significant at the $5 \%$ level, showing that the senior CEOs are more inclined to disclose goodwill impairment and disclose a larger amount of goodwill impairment. The coefficients of Propgw are all positive significantly, suggesting that larger amount of goodwill in the balance sheet affects goodwill impairment disclosure. The coefficients of BTM and Age are negitive significant, which are consistent with the findings of the existing literature.

Table 6

Regression Analysis of the Impact of Agency Motivation on the Signal Effect of Performance Compensation Commitment

\begin{tabular}{|c|c|c|c|}
\hline & $\begin{array}{c}\text { (1) } \\
\text { Imp_dum }\end{array}$ & $\begin{array}{l}(2) \\
\text { Imp }\end{array}$ & $\begin{array}{l}\text { (3) } \\
\text { Imp }\end{array}$ \\
\hline Propmi & $\begin{array}{c}18.286^{* * * *} \\
(2.82)\end{array}$ & $\begin{array}{c}0.017 * * * \\
(3.77)\end{array}$ & $\begin{array}{c}0.187 * * * \\
(8.62)\end{array}$ \\
\hline Ret & $\begin{array}{l}-0.016 \\
(-0.03)\end{array}$ & $\begin{array}{l}-0.001 \\
(-1.62)\end{array}$ & $\begin{array}{l}-0.006 \\
(-1.04)\end{array}$ \\
\hline ProxRet & $\begin{array}{c}-3.038^{* * *} \\
(-3.92)\end{array}$ & $\begin{array}{l}-0.001 \\
(-0.61)\end{array}$ & $\begin{array}{l}-0.003 \\
(0.22)\end{array}$ \\
\hline Lev & $\begin{array}{c}2.755^{* *} \\
(2.22)\end{array}$ & $\begin{array}{l}0.004 \\
(1.18)\end{array}$ & $\begin{array}{c}0.052 * * * \\
(2.88)\end{array}$ \\
\hline ProxLev & $\begin{array}{r}-14.174 \\
(-0.84)\end{array}$ & $\begin{array}{c}-0.023 * * \\
(-2.50)\end{array}$ & $\begin{array}{c}-0.183 * * * \\
(-4.86)\end{array}$ \\
\hline Loss_dum & $\begin{array}{l}-0.215 \\
(-0.20)\end{array}$ & $\begin{array}{c}0.014 * * * \\
(3.08)\end{array}$ & $\begin{array}{c}0.036 * * * \\
(3.65)\end{array}$ \\
\hline ProxLoss & $\begin{array}{c}61.275^{* * * *} \\
(2.96)\end{array}$ & $\begin{array}{c}0.059^{* * *} \\
(9.30)\end{array}$ & $\begin{array}{l}0.019 \\
(1.08)\end{array}$ \\
\hline Gov & $\begin{array}{l}-0.419 \\
(-0.39)\end{array}$ & $\begin{array}{l}0.002 \\
(1.40)\end{array}$ & $\begin{array}{l}-0.006 \\
(-0.47)\end{array}$ \\
\hline CEOTurnover & $\begin{array}{l}0.550 \\
(1.34)\end{array}$ & $\begin{array}{l}-0.001 \\
(-1.49)\end{array}$ & $\begin{array}{l}0.004 \\
(0.67)\end{array}$ \\
\hline CEOAge & $\begin{array}{c}0.064 * * \\
(2.07)\end{array}$ & $\begin{array}{l}0.000 \\
(0.49)\end{array}$ & $\begin{array}{l}0.001 * \\
(1.92)\end{array}$ \\
\hline Size & $\begin{array}{l}0.156 \\
(0.45)\end{array}$ & $\begin{array}{l}0.001 \\
(1.43)\end{array}$ & $\begin{array}{l}0.002 \\
(0.40)\end{array}$ \\
\hline Propgw & $\begin{array}{c}3.803 * * \\
(2.09)\end{array}$ & $\begin{array}{c}0.019 * * * \\
(3.60)\end{array}$ & $\begin{array}{c}0.121^{* * *} \\
(5.91)\end{array}$ \\
\hline BTM & $\begin{array}{l}-0.061 \\
(-0.08)\end{array}$ & $\begin{array}{l}-0.001 \\
(-1.32)\end{array}$ & $\begin{array}{l}0.001 \\
(0.16)\end{array}$ \\
\hline Age & $\begin{array}{c}-0.127 * * * \\
(-2.67)\end{array}$ & $\begin{array}{l}-0.000^{*} \\
(-1.73)\end{array}$ & $\begin{array}{c}-0.001 * * \\
(-2.41)\end{array}$ \\
\hline _cons & $\begin{array}{l}-14.626 \\
(-0.20)\end{array}$ & $\begin{array}{l}-0.003 \\
(-0.87)\end{array}$ & $\begin{array}{c}-0.159 * * * \\
(-4.35)\end{array}$ \\
\hline Year & Yes & Yes & Yes \\
\hline Ind & Yes & Yes & Yes \\
\hline $\mathrm{N}$ & 990 & 990 & 990 \\
\hline $\begin{array}{l}\text { Adj.R-Square/ } \\
\text { Pseudo.R-Square }\end{array}$ & 0.660 & 0.558 & 0.478 \\
\hline
\end{tabular}

Note: $* * *, * *$ indicate statistical significance at the $10 \%, 5 \%$, and $1 \%$ levels, respectively. $t$-values in parentheses.

Table 6 displays the results of the regression analysis of agency motivation on the signal effect of performance compensation commitment. The first column is the regression result of the binary logit model, the second column is the linear regression result of the ols model, and the third column is the censored regression result of the tobit model. The coefficient for the interaction between Propmi and Ret 
(ProxRet) is -3.038 , significant at the $1 \%$ level, and the coefficient for the interaction between Propmi and Lev (ProxLev) is $-0.023(-0.183)$, significant at the $1 \%$ and $5 \%$ level respectively. This indicates that agency motivation does affect the signal effect of performance compensation commitment on goodwill impairment. Specifically, stock market return pressure and debt contracting pressure will weaken the signal effect of performance compensation commitment on goodwill impairment. This results partially support the $\mathrm{H} 2 \mathrm{~A}$ and $\mathrm{H} 2 \mathrm{~B}$, that is, the market pressure affects managers' decision on whether to disclose goodwill impairment, and debt contracting pressure affects managers' decision to disclose the amount of goodwill impairment. The coefficient for the interaction between Propmi and Loss_dum (ProxLoss) is 61.275(0.059), significant at the $1 \%$ level. This indicates that the "big bath" motivation generated by performance loss will lead to the overexpression of the signal effect of performance compensation commitment on goodwill impairment. The results are consistent with the predictions of $\mathrm{H} 3 \mathrm{~A}$ and $\mathrm{H} 3 \mathrm{~B}$. The results of other control variables are consistent with the previous ones.

\section{Further Analysis}

Table 7

Regression Analysis of the Mitigation Effect of External Governance on Agency Problems of Goodwill Impairment

\begin{tabular}{|c|c|c|c|}
\hline & $\begin{array}{c}\text { (1) } \\
\text { Imp_dum }\end{array}$ & $\begin{array}{l}\text { (2) } \\
\text { Imp }\end{array}$ & $\begin{array}{l}\text { (3) } \\
\text { Imp }\end{array}$ \\
\hline Propmi & $\begin{array}{c}18.968^{* *} \\
(2.57)\end{array}$ & $\begin{array}{c}0.015^{* * *} \\
(3.06)\end{array}$ & $\begin{array}{c}0.179 * * * \\
(7.89)\end{array}$ \\
\hline Ret & $\begin{array}{l}-0.054 \\
(-0.10)\end{array}$ & $\begin{array}{l}-0.001 \\
(-1.48)\end{array}$ & $\begin{array}{l}-0.006 \\
(-0.98)\end{array}$ \\
\hline ProxRet & $\begin{array}{l}2.110 \\
(0.28)\end{array}$ & $\begin{array}{c}-0.009 * * \\
(-2.57)\end{array}$ & $\begin{array}{l}0.042 \\
(1.12)\end{array}$ \\
\hline AuditxProxRet & $\begin{array}{l}-0.000 \\
(-0.76)\end{array}$ & $\begin{array}{c}0.000^{*} \\
(1.67)\end{array}$ & $\begin{array}{l}-0.000 \\
(-1.14)\end{array}$ \\
\hline Lev & $\begin{array}{c}3.021^{* *} \\
(2.02)\end{array}$ & $\begin{array}{l}0.005 \\
(1.51)\end{array}$ & $\begin{array}{c}0.047^{* *} \\
(2.50)\end{array}$ \\
\hline ProxLev & $\begin{array}{c}-20.281 \\
(-0.84)\end{array}$ & $\begin{array}{l}-0.022 * \\
(-1.77)\end{array}$ & $\begin{array}{c}-0.108 * * \\
(-2.15)\end{array}$ \\
\hline AuditxProxLev & $\begin{array}{l}0.000 \\
(0.92)\end{array}$ & $\begin{array}{l}0.000 \\
(1.32)\end{array}$ & $\begin{array}{l}0.000^{*} \\
(-1.69)\end{array}$ \\
\hline Loss_dum & $\begin{array}{l}0.291 \\
(0.26)\end{array}$ & $\begin{array}{c}0.013^{* * *} \\
(2.86)\end{array}$ & $\begin{array}{c}0.036^{* * *} \\
(3.60)\end{array}$ \\
\hline ProxLoss & $\begin{array}{c}407.047 * * \\
\quad(2.00)\end{array}$ & $\begin{array}{c}0.092 * * * \\
(4.95)\end{array}$ & $\begin{array}{l}0.023 \\
(0.68)\end{array}$ \\
\hline AuditxProxLoss & $\begin{array}{c}-0.000 * * \\
(-2.03)\end{array}$ & $\begin{array}{c}-0.000 * * \\
(-2.52)\end{array}$ & $\begin{array}{l}-0.000 \\
(-0.50)\end{array}$ \\
\hline Gov & $\begin{array}{l}-0.796 \\
(-0.69)\end{array}$ & $\begin{array}{l}0.001 \\
(1.31)\end{array}$ & $\begin{array}{l}-0.005 \\
(-0.44)\end{array}$ \\
\hline CEOTurnover & $\begin{array}{l}0.591 \\
(1.38)\end{array}$ & $\begin{array}{l}-0.001 \\
(-1.46)\end{array}$ & $\begin{array}{l}0.003 \\
(0.55)\end{array}$ \\
\hline CEOAge & $\begin{array}{c}0.074 * * \\
(2.30)\end{array}$ & $\begin{array}{l}0.000 \\
(0.59)\end{array}$ & $\begin{array}{c}0.001 * * \\
(2.14)\end{array}$ \\
\hline Size & $\begin{array}{l}0.093 \\
(0.26)\end{array}$ & $\begin{array}{l}0.001 * \\
(1.81)\end{array}$ & $\begin{array}{l}0.003 \\
(0.66)\end{array}$ \\
\hline Propgw & $\begin{array}{c}3.732 * * \\
(2.04)\end{array}$ & $\begin{array}{c}0.020^{* * * *} \\
(3.62)\end{array}$ & $\begin{array}{c}0.121 * * * \\
\quad(5.87)\end{array}$ \\
\hline BTM & $\begin{array}{l}-0.110 \\
(-0.13)\end{array}$ & $\begin{array}{l}-0.001 \\
(-1.44)\end{array}$ & $\begin{array}{l}0.002 \\
(0.22)\end{array}$ \\
\hline Age & $\begin{array}{c}-0.120 * * \\
(-2.44)\end{array}$ & $\begin{array}{c}-0.000 * \\
(-1.82)\end{array}$ & $\begin{array}{c}-0.001 * * \\
(-2.32)\end{array}$ \\
\hline _cons & $\begin{array}{c}-15.714 \\
(-0.26)\end{array}$ & $\begin{array}{l}-0.005 \\
(-1.29)\end{array}$ & $\begin{array}{c}-0.180 * * * \\
(-4.61)\end{array}$ \\
\hline Year & Yes & Yes & Yes \\
\hline Ind & Yes & Yes & Yes \\
\hline $\mathrm{N}$ & 977 & 977 & 977 \\
\hline
\end{tabular}

\begin{tabular}{|c|c|c|c|}
\hline & (1) & (2) & (3) \\
\hline & Imp_dum & Imp & Imp \\
\hline $\begin{array}{l}\text { Adj.R-Square/ } \\
\text { Pseudo.R-Square }\end{array}$ & 0.672 & 0.574 & 0.344 \\
\hline
\end{tabular}

Table 7 examines the mitigation effect of external governance on agency problems of goodwill impairment. The first column is the regression result of the binary logit model, the second column is the linear regression result of the ols model, and the third column is the censored regression result of the tobit model. A large number of studies show that external governance forces, such as higher audit quality, will alleviate a company's agency problems. I use the audit fees of the company to refer to the audit quality (Audit). As shown by the empirical results of table 7 , although the coefficients for the interaction between Audit and ProxRet (ProxLev, ProxLoss) are small, they are all significant. This indicates that the higher the audit quality, the smaller the impact of market return pressure and debt contracting pressure on the signal effect of performance compensation commitment. This will also inhibit the incentive for managers to use goodwill impairment to perform a "big bath" when companies' performance has decreased. The results of other control variables are consistent with the previous ones.

Robustness Test

Table 8

\begin{tabular}{|c|c|c|}
\hline \multicolumn{3}{|c|}{ Heckman Two-Stage Regressions } \\
\hline & (1) & (2) \\
\hline & Imp_dum & Imp \\
\hline \multirow[t]{2}{*}{ Propmi } & $0.105 * * *$ & $0.004 * * *$ \\
\hline & $(4.29)$ & $(3.38)$ \\
\hline \multirow[t]{2}{*}{ Ret } & -0.012 & $-0.001 *$ \\
\hline & $(-1.07)$ & $(-1.81)$ \\
\hline \multirow[t]{2}{*}{ Lev } & 0.084 & $0.006 * * *$ \\
\hline & $(1.57)$ & $(2.65)$ \\
\hline \multirow[t]{2}{*}{ Loss_dum } & $0.141 * * *$ & $0.012 * * *$ \\
\hline & $(3.58)$ & $(7.11)$ \\
\hline \multirow[t]{2}{*}{ Gov } & -0.009 & 0.001 \\
\hline & $(-0.29)$ & $(0.38)$ \\
\hline \multirow[t]{2}{*}{ CEOTurnover } & -0.015 & -0.000 \\
\hline & $(-0.92)$ & $(-0.07)$ \\
\hline \multirow[t]{2}{*}{ CEOAge } & 0.001 & -0.000 \\
\hline & $(1.03)$ & $(-0.56)$ \\
\hline \multirow[t]{2}{*}{ Size } & 0.014 & -0.000 \\
\hline & $(1.07)$ & $(-0.67)$ \\
\hline \multirow[t]{2}{*}{ Propgw } & -0.005 & 0.003 \\
\hline & $(-0.07)$ & $(1.21)$ \\
\hline \multirow[t]{2}{*}{ BTM } & -0.059 & $-0.003 *$ \\
\hline & $(-1.52)$ & $(-1.91)$ \\
\hline \multirow[t]{2}{*}{ Age } & $-0.003 * *$ & -0.000 \\
\hline & $(-2.03)$ & $(-1.63)$ \\
\hline \multirow[t]{2}{*}{ _cons } & -0.001 & 0.004 \\
\hline & $(-0.01)$ & $(0.72)$ \\
\hline \multirow[t]{2}{*}{$\operatorname{Lambda}(\lambda)$} & -0.046 & .-0.001 \\
\hline & $(-0.52)$ & $(-0.32)$ \\
\hline Year & Yes & Yes \\
\hline Ind & Yes & Yes \\
\hline $\mathrm{N}$ & 425 & 425 \\
\hline
\end{tabular}

Note: $*, * * * *$ indicate statistical significance at the $10 \%, 5 \%$, and $1 \%$ levels, respectively. $t$-values in parentheses.

The results of the existing literature suggest that there may be a self-selection problem when the two parties in an M\&A sign a performance compensation commitment agreement. This paper controls for the possible endogeneity 
problem by using the Heckman two-stage model. First, I use the dummy variable of performance compensation commitment as the explanatory variable to perform probit regressions, and I calculate the inverse Mills index (lambda). Then, the calculated inverse Mills index is incorporated into the corresponding model for regression. The regression results show that the coefficients of lambda are -0.046 and -0.001 , which are not significant, indicating that there is no self-selection problem. Moreover, the coefficient of Propmi is 0.105 (0.004), significant at the $1 \%$ level, which indicates that a performance compensation commitment agreement is a suitable exogenous variable for studying goodwill impairment.

In addition, if the company performance of the seller is not as promised, it will face pressure related to performance compensation. Therefore, the achievement of the performance compensation commitment may also be manipulated by the seller. In this paper, the samples with performance compensation commitments that are fully achieved are deleted, leaving only the unrealized samples, and the above tests are repeated. The results are basically unchanged, indicating that the results are relatively robust.

\section{Conclusions}

This paper takes A-share listed companies in China that completed major asset restructuring from 2007 to 2017 as a sample and examines the signal effect of performance compensation commitment on the impairment of goodwill and the impact of agency motivations on signal effect. I find evidence suggesting that the higher the proportion of the unfulfilled performance compensation commitment is, the higher the probability of goodwill impairment and the greater the amount of goodwill impairment. In addition, agency motivations affect the signal effect of performance compensation commitment on the impairment of goodwill. Specifically, for companies facing market return pressure and debt contracting pressure, the signal effect of the performance compensation commitment on the impairment of goodwill will be weakened. Furthermore, companies with performance loss have the incentive to use goodwill impairment to carry out a "big bath" and the loss motivation will lead to the overexpression of the signal effect of performance compensation commitment on goodwill impairment.

The change in the accounting treatment of goodwill impairment should be used to better reflect the economic value of goodwill and to improve the quality of financial statements. However, due to the unverifiable discretion in the goodwill impairment test, which provides space for management's opportunistic behavior, it is difficult for external users to judge whether management's decision related to goodwill impairment is correct. This paper based on the proportion of the performance compensation commitment that M\&A targets achieve, studies the relationship between the performance compensation commitment of the M\&A targets and the goodwill impairment. Under the control of other influencing factors, it is found that the performance compensation commitment is positive significant related to the goodwill impairment. In addition, although the manager's agency motivations affect the relationship between performance compensation commitment and goodwill impairment, the signal effect of performance compensation commitment on goodwill impairment is still significant. The conclusions of this paper will help external users of financial statements better identify goodwill impairment risk and learn more about manager discretion related to goodwill impairment.

\section{References}

AbuGhazaleh, N. M., Al-Hares, O. M., \& Roberts, C. (2011). Accounting Discretion in Goodwill Impairments: UK Evidence. Journal of International Financial Management \& Accounting, 22, 165-204. http://doi.org/10.1111/j.1467646X.2011.01049.X

American Institute of Certified Public Accountants (AICPA). (1970). Accounting principles board opinion no. 17 intangible assets. New York: AICPA.

Ayres, D. R., Neal, T. L., Reid, L. C., \& Shipman, J. E. (2019). Auditing goodwill in the post-amortization era: Challenges for auditors. Contemporary Accounting Research, 36(1), 82-107. http://doi.org/10.1111/1911-3846.12423

Beatty, A., \& Weber, J. (2006). Accounting discretion in fair value estimates: An examination of SFAS 142 goodwill impairments. Journal of Accounting Research, 44(2), 257-288. http://doi.org/10.1111/j.1475-679X.2006.00200.x

Beatty, A., Ramesh, K., Weber, J., 2002. The importance of accounting changes in debt contracts: the cost of flexibility in covenant calculations. Journal of Accounting and Economics 33, 205-227. https://doi.org/10.1016/S0165-4101(02) 00046-0

Bens, D. A., Heltzer, W., \& Segal, B. (2011). The information content of goodwill impairments and SFAS 142. Journal of Accounting, Auditing \& Finance, 26(3), 527-555. https://doi.org/10.1177/0148558X11401551

Bostwick, E. D., Krieger, K., \& Lambert, S. L. (2016). Relevance of goodwill impairments to cash flow prediction and forecasting. Journal of Accounting, Auditing \& Finance, 31(3), 339-364. https://doi.org/10.1177/0148558X15596201

Cheng, Q., Cho, Y. J., \& Yang, H. (2018). Financial reporting changes and the internal information environment: Evidence from SFAS 142. Review of Accounting Studies, 23(1), 347-383. https://doi.org/10.1007/s11142-017-9437-8

Carcello, J. V., Neal, T. L., Reid, L. C., and Shipman, J. E. (2019). Auditor independence and fair value accounting: An examination of non-audit fees and goodwill impairments. Contemporary Accounting Research. https://doi.org/10. 1111/1911-3846.12514 
Chen, L. H., Krishnan, J., \& Sami, H. (2014). Goodwill impairment charges and analyst forecast properties. Accounting Horizons, 29(1), 141-169. https://doi.org/10.2308/acch-50941

CSRC Accounting Department. (2013). Study on the accounting treatment of contingent consideration in business combination. Finance \& Accounting, (10), 17-19.

Darrough, M. N., Guler, L., \& Wang, P. (2014). Goodwill impairment losses and CEO compensation. Journal of Accounting, Auditing \& Finance, 29(4), 435-463. http:// doi.org/10.1177/0148558X14537824

Dichev, I., \& Skinner, D. (2002). Large sample evidence on the debt covenant hypothesis. Journal of Accounting Research, 40, 1091-1123. https://doi.org/10.1111/1475-679X.00083

Financial Accounting Standards Board (FASB). (1995). Statement of financial accounting standards no.121. Accounting for the impairment of long-lived assets and for long-lived assets to be disposed of. Norwalk, CT: FASB.

Financial Accounting Standards Board (FASB). 2001. Statement of financial accounting standards no.142. Goodwill and other intangible assets. Norwalk, CT: FASB.

Filip, A., Jeanjean, T., \& Paugam, L. (2015). Using real activities to avoid goodwill impairment losses: Evidence and effect on future performance. Journal of Business Finance \& Accounting, 42(3/4), 515-554. https://doi.org/10.111 $1 /$ jbfa. 12107

Giner, B., \& Pardo, F. (2015). How Ethical are Managers' Goodwill Impairment Decisions in Spanish-Listed Firms? Journal of Business Ethics, 132(1), 21-40. http://doi.org/10.1007/s10551-014-2303-8

Glaum, M., Landsman, W. R., \& Wyrwa, S. (2018). Goodwill impairment: The effects of public enforcement and monitoring by institutional investors. The Accounting Review, 93(6), 149-180. https://doi.org/10.2308/accr-52006

Gu, F., \& Lev, B. (2011). Overpriced shares, ill-advised acquisitions, and goodwill impairment. The Accounting Review, 86(6), 1995-2022. https://doi.org/10.2308/accr-10131

Hamberg, M., Paananen, M., \& Novak, J. (2011). The Adoption of IFRS 3: the Effects of Managerial Discretion and Stock Market Reactions. European Accounting Review, 20, 263-88. http://doi.org/10.1080/09638181003687877

Hayn, C., \& Hughes, P. J. (2006). Leading indicators of goodwill impairment. Journal of Accounting, Auditing \& Finance, 21(3), 223-265. https://doi.org/10.1177/0148558X0602100303

Holthausen, R., \& Watts, R. (2001). The relevance of the value-relevance literature for financial accounting standard setting. Journal of Accounting and Economics 31, 3-75. https://doi.org/10.1016/S0165-4101(01)00029-5

Iatridis, G. E., \& Senftlechner, D. (2014). An Empirical Investigation of Goodwill in Austria: Evidence on Management Change and Cost of Capital. Australian Accounting Review, 24, 171-181. http://doi.org/10.1111/auar.12014

Jahmani, Y., Dowling, W. A., \& Torres, P. D. (2010). Goodwill Impairment: A New Window for Earnings Management. Journal of Business \& Economics Research, 8, 9-24. http://dx.doi.org/10.19030/jber.v8i2.669

Jarva, H. (2009). Do firms manage fair value estimates? An examination of SFAS 142 goodwill impairments. Journal of Business Finance \& Accounting, 36(9/10), 1059-1086. https://doi.org/10.1111/j.1468-5957.2009.02169.x

Jensen M. C., \& Meckling W. H. (1976). Theory of the Firm : Managerial Behavior, Agency Costs and Ownership Structure [J]. Journal of Financial Economics, 3, 305-360. https://doi.org/10.1016/0304-405X(76)90026-X

Knauer, T., \& Wohrmann, A. (2016). Market reaction to goodwill impairments. European Accounting Review, 25(3), 421449. https://doi.org/10.1080/09638180.2015.1042888

Kothari, S. P., Ramanna, K., \& Skinner, D. J. (2010). Implications for GAAP from an analysis of positive research in accounting. Journal of Accounting and Economics, 50(2/3), 246-286. https://doi.org/10.1016/j.jacceco.2010.09.003

Lapointe-Antunes, P., Cormier, D., \& Magnan, M. (2008). Equity Recognition of Mandatory Accounting Changes: The Case of Transitional Goodwill Impairment Losses. Canadian Journal of Administrative Sciences, 25, 37-54. http:// doi.org/10.1002/cjas.41

Lee, C. (2011). The effect of SFAS 142 on the ability of goodwill to predict future cash flows. Journal of Accounting and Public Policy, 30(3), 236-255. https://doi.org/10.1016/j.jaccpubpol.2010.11.001

Li, K. K., \& Sloan, R. G. (2017). Has goodwill accounting gone bad? Review of Accounting Studies, 22(2), 964-1003. https://doi.org/10.1007/s11142-017-9401-7

Li, Z., Shroff, P. K., Venkataraman, R., \& Zhang, I. X. (2011). Causes and consequences of goodwill impairment losses. Review of Accounting Studies, 16(4), 745-778. https://doi.org/10.1007/s11142-011-9167-2

Lv, C. J., \& Han, H. B. (2014). VAM, synergy and distribution of gains from M\&A. Audit and Economic Research, (6), $3-13$.

Onesti, T., \& Romano, M. (2012). Earnings Management and Goodwill Accounting: Implications on Dividend Policy inItalian Listed Companies. Review of Accounting and Finance, 4, 55-74. http://dx.doi.org/10.2139/ssrn.2179159 
Qu, X. H., Lu, Y., \& Zang, R. L. (2017). Value relevance of goodwill impairments: empirical evidence from Chinese AShare Market. Research on Economics and Management, 38 (3), 122-132.

Ramanna, K. (2008). The implications of unverifiable fair-value accounting: Evidence from the political economy of goodwill accounting. Journal of Accounting and Economics, 45(2/3), 253-281. https://doi.org/10.1016/j.jacceco. 2007.11.006

Ramanna, K., \& Watts, R. L. (2012). Evidence on the use of unverifiable estimates in required goodwill impairment. Review of Accounting Studies, 17(4), 749-780. http://doi.org/10.1007/s11142-012-9188-5

Rehman I. R., \& Shahzad F. (2014). The Economic Consequences of Mandatory IFRS Reporting: Emerging Market Perspective. Inzinerine Ekonomika-Engineering Economics, 25(4), 401-409. http://doi.org/10.5755/j01.ee.25.4.2775

Sapkauskiene, A., Leitoniene, S., \& Vainiusiene, E. (2016). Disclosure of goodwill impairment in the Baltic states. Inzinerine Ekonomika -Engineering Economics, 27(4), 417-429. http://doi.org/10.5755/j01.ee.27.4.15360

Wang, J. H., Jia, J., \& Zhang, X. W. (2016). Mergers and acquisitions, "double high" high temperature does not retreat, evaluation agencies to do better and better to provide quality services. Appraisal Journal of China, (10), 39-44.

Xie, X. L. (2016). Research on performance compensation commitment in the process of M\&A of A-share listed companies. Times Finance, (8), 137, 151.

Zang, Y. (2008). Discretionary Behavior with Respect to the Adoption of SFAS no. 142 and the Behavior of Security Prices. Review of Accounting and Finance, 7, 38-68. http://dx.doi.org/10.1108/14757700810853842

Zhao, G. Q. (2012). Discussion on accounting and taxation treatment of assets injection performance failure compensation. Finance \& Accounting, (1), 48-50

The article has been reviewed. Received in March 2019; accepted in December 2019. 